\title{
Gabriela Centra transferu technologii i spółki Konopka-Cupiał celowe jako narzędzia komercjalizacji wyników badań naukowych w polskich uczelniach
}

Technology transfer centres and special purpose vehicles as tools for commercialisation of scientific research at Polish universities

This article presents an overview of basic issues related to the knowledge and technology transfer at Polish universities. First, the activities of technology transfer centres and special purpose vehicles are presented. Next, the key stages of the commercialization process are discussed with particular emphasis on its financial and legal aspects. In the final section the activities of the Polish Association of Centres for Technology Transfer are described.

\begin{tabular}{r|l}
\hline DOI & https://doi.org/10.31268/StudiaBAS.2020.05 \\
\hline Słowa kluczowe & $\begin{array}{l}\text { komercjalizacja badań naukowych w Polsce, transfer wiedzy } \\
\text { i technologii w Polsce, centrum transferu technologii, spółka celowa, } \\
\text { Porozumienie Akademickich Centrów Transferu Technologii }\end{array}$ \\
\hline Keywords & $\begin{array}{l}\text { commercialisation of scientific research in Poland, knowledge and } \\
\text { technology transfer in Poland, technology transfer centre, special } \\
\text { purpose vehicle, Polish Association of Centres for Technology Transfer }\end{array}$ \\
\hline 0 autorce & $\begin{array}{l}\text { doktor inż., dyrektor Centrum Transferu Technologii, Uniwersytet } \\
\text { Jagielloński } ・ \text { gabriela.konopka-cupial@uj.edu.pl } \\
\text { ORCID 0000-0002-4626-7478 }\end{array}$ \\
\hline
\end{tabular}

\section{Wstęp}

Celem artykułu jest przybliżenie tematyki dotyczącej komercjalizacji wyników badań w polskich uczelniach i pokazanie roli, jaką spełniają w tym procesie centra transferu technologii oraz spółki celowe.

W opracowaniu przedstawiono podstawowe zagadnienia związane z transferem wiedzy i technologii w polskich uczelniach. Odnosząc się do obowiązujących przepisów prawa, zdefiniowano centrum transferu technologii oraz spółkę celową jako jednostki otoczenia biznesu powoływane w uczelniach wyższych w celu komercjalizacji wyników badań naukowych. W dalszej kolejności przedstawiono zakresy działalności tych jednostek na przykładach wybranych polskich uczelni. Wchodząc głębiej w sam proces komercjalizacji na przykładzie Centrum Transferu Technologii CITTRU Uniwersytetu Jagiellońskiego (dalej: CTT CITTRU), zaprezentowano najważniejsze etapy tego procesu. W publikacji poruszono także zagadnienia związane z realiami finansowymi uczelnianych jednostek zajmujących się komercjalizacją wyników badań. Na zakończenie przedstawiono działalność Porozumienia Akademickich Centrów Transferu Technologii, ogólnopolskiej sieci jednostek zajmujących się transferem technologii w uczelniach wyższych. 


\section{Podmioty otoczenia biznesu funkcjonujące na uczelni}

Współpraca uczelni wyższych z podmiotami gospodarczymi w ciągu ostatnich lat stała się nie tylko elementem zapisanym w misji nowoczesnego, idącego z duchem czasu uniwersytetu, ale rzeczywistym działaniem przynoszącym realne korzyści zaangażowanym stronom. W strukturach uczelni na stałe zagościły więc instytucje otoczenia biznesu, takie jak centra transferu technologii (dalej: CTT) i spółki celowe (dalej: SC). Te pierwsze, zgodnie z obowiązującymi przepisami ${ }^{1}$ zajmują się przede wszystkim komercjalizacją bezpośrednią zdefiniowaną jako: sprzedaż wyników działalności naukowej lub know-how zwiqzanego z tymi wynikami albo oddawanie do użytku tych wyników (art. 148 ust. 4 u.p.s.w.i.n). Spółki celowe natomiast, czyli jednoosobowe spółki kapitałowe, w swoim zakresie działania w głównej mierze skupiają się na: komercjalizacji pośredniej, polegającej na obejmowaniu lub nabywaniu udziałów lub akcji w spółkach lub obejmowaniu warrantów subskrypcyjnych uprawniających do zapisu lub objęcia akcji w spółkach w celu wdrożenia lub przygotowania do wdrożenia wyników działalności naukowej (art. 149 ust. 1 u.p.s.w.i.n). Ponadto: uczelnia w drodze umowy, może powierzyć spółce celowej zarzq̨dzanie prawami do wyników badań (art. 149 ust. 2 u.p.s.w.i.n), czyli scedować na spółkę zadania związane z komercjalizacją bezpośrednią. Uczelnie decydują więc, czy w swoich strukturach chcą wyodrębnić dwa niezależne podmioty, każdy do innego zakresu związanego z komercjalizacją, czy tylko jeden z nich.

W polskim uczelniano-innowacyjnym ekosystemie dominującymi podmiotami wyodrębnionymi najczęściej zgodnie z rekomendacją ustawową jako jednostki ogólnouczelniane są centra transferu technologii. Na przykład w Uniwersytecie Jagiellońskim od 2002 r. za zadania związane z komercjalizacją pośrednią odpowiada Centrum Transferu Technologii CITTRU (do 2015 r. Centrum Innowacji Transferu Technologii i Rozwoju Uniwersytetu). Jest to jedno ze starszych, ale nie najstarsze polskie CTT. Pierwsze jednostki tego typu powstały w Poznaniu (Fundacja Uniwersytetu im. Adama Mickiewicza w Poznaniu działa od 1990 r., czyli w roku bieżącym będzie obchodzić 30-lecie swojej działalności), we Wrocławiu (Wrocławskie Centrum Transferu Technologii Politechniki Wrocławskiej zostało powołane w 1995 r.) czy w Warszawie (Uniwersytecki Ośrodek Transferu Technologii Uniwersytetu Warszawskiego powstał w 1998 r.). Łączy je jedno: podejmowanie działań mających na celu udostępnienie podmiotom zewnętrznym (przedsiębiorstwom, instytucjom administracji publicznej, organizacjom pożytku publicznego) rezultatów uzyskiwanych przez zespoły naukowe w projektach badawczych w sposób umożliwiający ich wykorzystanie w działalności własnej przez te podmioty.

\section{Zakres działalności CTT i SC}

Mimo wspólnego nadrzędnego celu, jakim jest komercjalizacja bezpośrednia uczelniane centra transferu technologii różnią się między sobą zakresem podejmowanych działań zarówno w obrębie i na rzecz samej uczelni, jak i w formułowaniu oferty dla biznesu. Część z nich, np. CTT CITTRU,

Ustawa z 20 lipca 2018 r. - Prawo o szkolnictwie wyższym i nauce, Dz.U. poz. 1668; dalej: prawo o szkolnictwie wyższym lub u.p.s.w.i.n. 
skupia się przede wszystkim na klientach wewnętrznych, tj. pracownikach naukowych, którzy chcą wyjść do biznesu z ofertą na opracowane przez siebie innowacyjne produkty i usługi oraz zaangażować się w proces ich komercjalizacji, lub też są zainteresowani świadczeniem komercyjnych usług badawczych. Pracownicy CTT poszukują więc dla nich odpowiednich partnerów biznesowych, którzy są gotowi zaangażować się we wdrażanie uniwersyteckich innowacji lub poszukują dostępu do specjalistycznej infrastruktury badawczej i uniwersyteckiej wiedzy eksperckiej. Tym samym CTT CITTRU zajmuje się nie tylko komercjalizacją bezpośrednią jako taką, ale także formalną obsługą sprzedaży komercyjnych usług badawczych w uczelni (tzw. badaniami zleconymi).

Inaczej wygląda to w ofercie wspomnianego wyżej wrocławskiego WCTT, CTT Politechniki Krakowskiej czy też Regionalnego Centrum Innowacji i Transferu Technologii ZUT w Szczecinie. W tych jednostkach oprócz klasycznych aktywności związanych z komercjalizacją uniwersyteckiej wiedzy znaleźć można bogatą ofertę usług dla biznesu, takich jak audyty technologiczne, szkolenia i doradztwo, pomoc w uzyskaniu dofinansowania na prowadzenie działalności, a także w ekspansji na rynki międzynarodowe. Wymienione CTT w swojej strukturze mają regionalne punkty kontaktowe sieci EEN (Enterprise Europe Network) - największej na świecie sieci wsparcia współpracy technologicznej i handlowej, dającej możliwość nawiązywania kontaktów międzynarodowych przedsiębiorstwom i instytucjom zrzeszonym w sieci. To m.in. dzięki tej sieci, a także przez realizację projektów finansowanych, np. z programów regionalnych, uczelniane CTT mogą poszerzyć swoją ofertę o usługi nie tylko wspierające naukowca w skomercjalizowaniu uniwersyteckich wynalazków, ale także przedsiębiorcę w rozwoju jego działalności.

Efektem pracy kadry z centrów transferu technologii niejednokrotnie są także wspólne projekty badawczo-rozwojowe realizowane w partnerstwie naukowo-biznesowym. Skorzystanie z dofinansowania oferowanego np. przez Narodowe Centrum Badań i Rozwoju (NCBR), Polską Agencję Rozwoju Przedsiębiorczości (PARP) lub agencje regionalne pozwala zminimalizować ryzyko niepowodzenia, jakie zawsze jest związane z rozwojem i wdrażaniem nowych, innowacyjnych i niestandardowych produktów i usług. W szczególności tych wymyślanych w akademickich laboratoriach, których poziom gotowości technologicznej najczęściej jest niski. Stąd też wspólny projekt badawczo-rozwojowy to dobry sposób na dalszy rozwój uczelnianych technologii we współpracy z przedsiębiorcą, który po zakończeniu projektu weźmie na siebie ciężar wdrożenia uzyskanych rezultatów. Wspólne przedsięwzięcia projektowe to również doskonała okazja do budowania wzajemnego zaufania, którego brak wymieniany jest jako jedna z podstawowych barier we współpracy nauki z biznesem.

Na polu aranżowania projektów łączących środowisko naukowe z biznesowym swoimi sukcesami mogą pochwalić się także spółki celowe. Jednostki te, skupiając uwagę w głównej mierze na wspieraniu naukowców w procesie zakładania i rozwoju startupów, z dużym powodzeniem identyfikują również inne potrzeby przedsiębiorców. Oferują im więc rozwiązania, korzystając przy tym z infrastruktury oraz wiedzy eksperckiej uczelni. Sukcesy na tym polu odnoszą m.in. Spółka Celowa Uniwersytetu Ekonomicznego w Poznaniu sp. z o.o. (SCUEP) czy też Instytut Innowacji i Technologii Politechniki Białostockiej sp. z o.o. (IIiTPB). Ta pierwsza, jako spółka uczelni ekonomicznej, pozyskuje i realizuje projekty rozwojowe, w których kluczową rolę odgrywa wiedza i kompetencje pracowników naukowych i studentów tej uczelni. Od początku 
swojej działalności, tj. w okresie 5 lat SCUEP może pochwalić się realizacją 250 projektów dla 140 przedsiębiorstw i instytucji publicznych. Projekty te dotyczą głównie rozwoju strategicznego przedsiębiorstw. Efektami prac zaaranżowanych i koordynowanych przez tę spółkę celową są modele biznesowe, strategie rozwoju oraz nowe produkty ${ }^{2}$.

Nie tylko Uniwersytet Ekonomiczny w Poznaniu powierzył spółce celowej oferowanie w jej imieniu komercyjnych usług badawczo-eksperckich podmiotom biznesowym. To samo zrobiły m.in. Politechnika Białostocka, Politechnika Gdańska czy Uniwersytet Śląski. Politechnika Białostocka jest przykładem uczelni, która zrezygnowała z powoływania centrum transferu technologii i posiadania dwóch odrębnych podmiotów zajmujących się komercjalizacją. Instytut Innowacji i Technologii Politechniki Białostockiej sp. z o.o. realizuje zadania zarówno w zakresie komercjalizacji pośredniej, jak i bezpośredniej. W imieniu i na rzecz uczelni oferuje także dostęp do infrastruktury badawczej będącej w posiadaniu Politechniki. W ramach IIiTPB oprócz Biura Transferu Technologii, Akademickiego Inkubatora Przedsiębiorczości i Wybranych Nowych Technologii Politechniki Białostockiej działa także Zakład Produkcji Doświadczalnej i Usług Technicznych ${ }^{3}$. Oznacza to, że w jednym podmiocie skupiono wszystkie kompetencje i aktywności wspierające współpracę nauki z biznesem i regionem.

Omawiając sposób organizacji i funkcjonowanie uczelnianych SC i CTT, należy zauważyć, że niektóre uczelnie, mimo że fizycznie wyodrębniają dwie niezależne jednostki do realizacji zadań związanych z komercjalizacją, to jednak decydują się na unię personalną między nimi. Przykładem może być wspomniana już Politechnika Gdańska, ale także Akademia Górniczo-Hutnicza czy Uniwersytet Rolniczy w Krakowie. W uczelniach tych co najmniej jeden z członków kadry zarządzającej SC i CTT to ta sama osoba. Sprzyja to unifikacji podejścia do zadań związanych z komercjalizacją uczelnianych technologii i współdziałaniu w osiąganiu celów dla tej samej Alma Mater.

Podsumowując zakres działalności centrów transferu technologii i spółek celowych, należy wspomnieć, że na wielu stronach internetowych tych jednostek można znaleźć bazy uczelnianych technologii i usług badawczych (np. http://www.sciencemarket.pl - baza prowadzona przez CTT CITTRU), co ma ułatwić identyfikację komercyjnej oferty jednostek naukowych oraz bezpośrednie dotarcie przedsiębiorcy do zespołu naukowego zainteresowanego współpracą. Ponadto jedni i drudzy oferują zarówno studentom, doktorantom, naukowcom, jak i przedstawicielom biznesu liczne szkolenia z zakresu ochrony i wdrażania własności intelektualnej oraz szeroko rozumianej przedsiębiorczości akademickiej, w tym rozwoju kompetencji studentów oraz kadry akademickiej.

\section{Proces komercjalizacji na przykładzie CTT CITTRU}

Aby przyjrzeć się bliżej działaniom podejmowanym przez CTT i SC w drodze, jaką należy pokonać od uniwersyteckiego pomysłu do produktu oferowanego docelowemu odbiorcy, prześledzić

\footnotetext{
2 Https://scuep.pl/.

3 Http://instytutpb.com/.
} 
można etapy procesu transferu technologii, którymi podążają pracownicy Centrum Transferu Technologii CITTRU Uniwersytetu Jagiellońskiego wraz z naukowcami, twórcami z tej uczelni. Kilkunastoletnia działalność CTT CITTRU oraz liczne przypadki efektywnej współpracy z przedsiębiorcami umożliwiają wskazanie najbardziej istotnych elementów udanego procesu komercjalizacji wyników badań naukowych ${ }^{4}$. Mimo indywidualnego charakteru każdego wynalazku proces ten obejmuje za każdym razem pewne stałe elementy. Komercjalizacja uniwersyteckiej wiedzy i technologii to najczęściej złożony, wielomiesięczny, czasochłonny i kapitałochłonny proces obejmujący po stronie uczelni konieczność:

- objęcia wyników badań ochroną prawną, np. patentową,

- określenia produktów i usług, jakie mogą powstać z wykorzystaniem tej wiedzy i technologii,

- weryfikacji wartości rynkowej tych produktów i usług oraz technologii jako takiej,

- identyfikacji potencjalnych odbiorców i efektywnej promocji pozwalającej do nich dotrzeć,

- wykonania kolejnych badań i prac rozwojowych.

Proces ten rozpoczyna się od dotarcia przez brokera (pracownika CTT odpowiedzialnego za realizację procesu komercjalizacji) do zespołu naukowego, który stworzył ciekawe rozwiązanie mające rynkowy potencjał. Po formalnościach związanych ze zgłoszeniem wyników badań do CTT CITTRU (konieczne jest, aby zespół naukowy złożył podpisany przez wszystkich twórców oraz kierownika jednostki, z której pochodzą twórcy, formularz zgłoszenia wyników) broker, wykorzystując dostępne zasoby wiedzy, w tym komercyjne bazy danych i raporty rynkowe, przeprowadza wstępną analizę potencjału rynkowego i zdolności patentowej ewentualnego wynalazku. Jednocześnie, na samym początku procesu konieczne jest precyzyjne określenie dysponentów praw majątkowych do zgłoszonych rezultatów prac badawczych i ich zabezpieczenie na rzecz uczelni lub uczelni i innych współuprawnionych. Udział studentów, doktorantów bądź innych osób niebędących pracownikami uniwersytetu wymusza konieczność umownego uregulowania przynależności praw majątkowych do rezultatów badawczych, zasad komercyjnego wykorzystania tych praw i przyszłych beneficjentów procesu komercjalizacji. Na tym etapie podpisywane są nie tylko umowy z twórcami wynalazków, ale innymi podmiotami uprawnionymi z przyszłego patentu. W umowach tych regulowane są prawa i obowiązki współuprawnionych oraz twórców.

Należy w tym miejscu wspomnieć, że prawo o szkolnictwie wyższym stwarza pracownikom uczelni możliwość przejęcia praw majątkowych do wytworzonych przez nich wyników badań naukowych (w tym wynalazków, wzorów użytkowych, wzorów przemysłowych, topografii układów scalonych, odmian roślin), prac rozwojowych czy też twórczości artystycznej. Co do zasady pierwotnym właścicielem i dysponentem tych praw jest uczelnia jako pracodawca ${ }^{5}$. Prawo o szkolnictwie wyższym pozwala jednak pracownikowi uczelni publicznej na zgłoszenie zainteresowania przeniesieniem na niego praw do tych wyników. Pisemne oświadczenie w tej sprawie pracownik może złożyć w terminie 14 dni od dnia przekazania uczelni informacji o wynikach

4 G. Konopka-Cupiał, Komercjalizacja wyników badań naukowych spod znaku UJ, „Alma Mater” 2017, nr 196.

5 Uczelnia nie jest wyjątkiem w tym względzie zgodnie z ustawą z 30 czerwca 2000 r. - Prawo własności przemysłowej, Dz.U. 2001, nr 49, poz. 508, ze zm. 
swojej działalności naukowej (w UJ jest to 14 dni od złożenia w CTT CITTRU podpisanego formularza zgłoszenia wyników). Wówczas uczelnia ma 3 miesiące na decyzję o przekazaniu praw majątkowych pracownikowi, a tym samym wyrażenie zgody na samodzielną komercjalizację rezultatów przejętych przez twórcę. Przeniesienie to następuje na podstawie odpłatnej umowy. Wysokość wynagrodzenia należnego uczelni jest jednak zdefiniowana przez prawo o szkolnictwie wyższym. Nie może być ono wyższe niż 5\% przeciętnego wynagrodzenia, ogłaszanego przez GUS za rok poprzedni, niezależnie od wysokości nakładów, jakie poniosła uczelnia na uzyskanie tych rezultatów badawczych.

W zależności od tego, kto stanie się ostatecznym dysponentem praw majątkowych, różnie później dzielone są korzyści uzyskane z komercjalizacji. Na sposób rozliczania się naukowca z uczelnią bądź uczelni z naukowcem również mają wpływ przepisy prawa o szkolnictwie wyższym. Mówią one o tym, że: w przypadku komercjalizacji dokonywanej przez uczelnię: pracownikowi przysługuje od uczelni publicznej nie mniej niż 50\% wartości środków uzyskanych przez uczelnię z komercjalizacji bezpośredniej, obniżonych o nie więcej niż 25\% kosztów bezpośrednio zwiq̨zanych z tq komercjalizacja, które zostały poniesione przez uczelnię lub spółkę celowq oraz 50\% wartości środków uzyskanych przez spółkę celowq w następstwie danej komercjalizacji pośredniej, obniżonych o nie więcej niż 25\% kosztów bezpośrednio zwiqzanych z tą komercjalizacja, które zostały poniesione przez uczelnię lub spółkę celową. [...] W przypadku komercjalizacji dokonanej przez pracownika, uczelni publicznej przysługuje 25\% wartości środków uzyskanych przez pracownika z komercjalizacji, obniżonych o nie więcej niż 25\% kosztów bezpośrednio zwiqzanych z tą komercjalizacja, które zostały poniesione przez pracownika (art. 155 ust. 1 i 2. u.p.s.w.i.n.). Zasady te, podobnie jak pozostałe prawa i obowiązki uczelni i pracownika, zgodnie z wytycznymi prawa o szkolnictwie wyższym, są ujmowane w uczelnianych regulaminach zarządzania prawami autorskimi, prawami pokrewnymi i prawami własności przemysłowej oraz zasadach komercjalizacji. Minimalne wymagania określa ustawa, natomiast o stopniu szczegółowości przepisów wewnętrznych decyduje jednak uczelnia. W UJ pierwszy regulamin tego typu został przyjęty w 2007 r., jeszcze przed ustawowym wymogiem jego posiadania (obowiązujący regulamin został uchwalony w 2015 r.). Obecnie każda uczelnia posiada stosowne regulacje. Niektóre, aby zmotywować jeszcze bardziej swoich pracowników do współdziałania w procesie komercjalizacji, oddają im więcej niż ustawowe 50\% korzyści. W UJ wartość tę zwiększono do 60\%.

Wracając do opisu etapów procesu transferu technologii: po zdefiniowaniu i zabezpieczeniu praw dysponentów do wyników badań, w przypadku obiecujących rezultatów analiz, o których mowa wyżej, twórcy wynalazku, rzecznik patentowy oraz broker podejmują działania zmierzające do zapewnienia optymalnej ochrony prawnej (jeśli to możliwe patentowej), dającej możliwość zagwarantowania monopolu prawnego na kluczowych rynkach zbytu przyszłych produktów i usług, w kraju i za granicą. Niezwłocznie po dokonaniu zgłoszenia patentowego określana jest optymalna ścieżka wdrożenia wynalazku uwzględniająca możliwości i chęci zaangażowania się twórców w ten proces oraz poziom gotowości technologicznej proponowanego rozwiązania. Rozpoczyna się także intensywna promocja wśród potencjalnych partnerów biznesowych (w zależności od wybranej ścieżki komercjalizacji wśród inwestorów branżowych bądź kapitałowych). Przydatnym wówczas narzędziem w pracy brokera są oferty technologiczne, które 
można zaprezentować potencjalnym partnerom biznesowym. Na pierwszym etapie poszukiwań i rozmów z ewentualnymi biorcami wynalazków możliwe jest stworzenie i wykorzystanie ogólnej oferty, w której na tle stanu techniki podkreśla się zalety i przewagi konkurencyjne oferowanego wynalazku. Każda kolejna rozmowa z potencjalnymi licencjobiorcą lub inwestorem kapitałowym wymaga już od brokerów bardziej szczegółowej wiedzy na temat produktów i usług, jakie można wytworzyć z wykorzystaniem wynalazku, rynków zbytu i trendów na nich panujących, potrzeb i możliwości konkretnego partnera biznesowego, z którym prowadzone są rozmowy, a tym samym stworzenia spersonalizowanej dla każdego partnera biznesowego indywidualnej oferty. Kluczowe są tu zatem umiejętności docierania do różnych informacji, wyciągania wniosków, analitycznego myślenia oraz słuchania tego, co mówi partner biznesowy, niezależnie, czy zajmuje się tym broker w CTT, specjalista ds. rozwoju biznesu technologicznego w SC, czy sam naukowiec.

Równolegle do aktywności związanych z poszukiwaniem odbiorców wynalazku brokerzy wspólnie z twórcami wynalazku opracowują plan jego dalszego rozwoju ukierunkowany na zwiększenie wartości rynkowej i atrakcyjności wśród partnerów biznesowych (zdecydowana większość wynalazków powstających na uczelniach jest na wczesnym lub bardzo wczesnym etapie gotowości technologicznej). Istotne jest, aby najszybciej jak to możliwe w planowanych pracach badawczo-rozwojowych uwzględniać informacje zebrane z rynku od inwestorów i użytkowników końcowych. Wdrożeniu uniwersyteckich technologii sprzyja także jak najwcześniejsze włączenie partnera biznesowego w podejmowane prace badawcze. Oczywiście zadanie dopracowania i stworzenia produktu gotowego do wejścia na rynek, spełniającego wszystkie normy i kryteria dopuszczenia do obrotu, należy do partnera biznesowego. Jednak trzeba pamiętać, że atrakcyjność wynegocjowanych na rzecz uczelni warunków umów komercjalizacyjnych w znacznym stopniu zależy od fazy rozwoju wynalazku, na bazie którego owe produkty czy usługi powstają. Na warunki zawieranych przez uczelnię umów w równie istotnym stopniu wpływa poziom i sposób bezpośredniego zaangażowania się twórców wynalazku w planowane przez przedsiębiorcę działania oraz otwartość naukowców na doradztwo i udział w dalszych pracach badawczo-rozwojowych. Nie bez znaczenia są także umiejętności i doświadczenie negocjacyjne brokerów z CTT.

Niezwykle istotna dla powodzenia komercjalizacji uniwersyteckich pomysłów jest ścisła współpraca i wzajemne zrozumienie się wszystkich podmiotów zaangażowanych w ten proces, tj. twórców wynalazku, pracowników CTT, rzeczników patentowych, przedsiębiorców i inwestorów. Ważna jest także elastyczność i umiejętność reagowania na artykułowane przez strony potrzeby.

Zwieńczeniem procesu komercjalizacji jest wynegocjowana i podpisana umowa, np. licencyjna lub sprzedaży praw do wynalazku. Jeśli strony zaangażowane w proces działają z dużym zrozumieniem każdego interesariusza, możliwe jest skonstruowanie takiej umowy, która daje poczucie sukcesu każdemu. Kompetencje kadry CTT lub SC, działającej na rzecz i w imieniu uniwersytetu, mają duży wpływ nie tylko na korzyści finansowe płynące z zawartego kontraktu zarówno dla samej uczelni, jak i twórców, ale także na bezpieczeństwo uczelni jako licencjodawcy czy sprzedawcy. 


\section{Finansowanie działalności związanej z komercjalizacją}

Jak już wyżej wspomniano, transfer technologii to proces wymagający czasu i kapitału, obarczony ryzykiem niepowodzenia zarówno po stronie naukowca, uczelni, jak i przedsiębiorcy. Ryzyko jest tym większe, im wcześniejszy etap rozwoju wdrażanego pomysłu oraz im trudniejsza i bardziej wymagająca branża. Inaczej wygląda możliwość wprowadzenia na rynek nowego narzędzia informatycznego, inaczej usprawnienia procesu technologicznego, np. chemicznego, czy urządzenia diagnostycznego, a jeszcze inaczej wdrożenie nowego leku, gdzie czas i kapitał potrzebny na wykonanie wszystkich niezbędnych badań i procedur oraz bariery wejścia nowego produktu na rynek są nieporównywalnie większe. Aby minimalizować ryzyko i uprawdopodobniać sukces, jakim jest nie tylko podpisanie umowy licencyjnej, ale przede wszystkim pojawienie się na rynku innowacyjnego produktu lub usługi, konieczny jest odpowiedni kapitał ludzki i środki finansowe. Pieniądze potrzebne są i na zatrudnienie odpowiedniego, wykwalifikowanego personelu, i na ochronę patentową w Polsce, a w wielu przypadkach także za granicą, bo niewiele jest teraz produktów, dla których rynek zbytu można ograniczyć do jednego państwa. Kolejne źródło kosztów to delegacje, targi i konferencje biznesowe, podczas których promowana jest oferta uczelni, a także materiały promocyjne (ulotki, broszury, filmy itp.), czy w dalszej kolejności prototypy i demonstratory. Doświadczenia ostatnich lat pokazały również, że ważne jest, aby CTT i SC dysponowały środkami na wykonanie szybkich badań uzupełniających dotychczasowe rezultaty uzyskane przez zespoły naukowe, których konieczność wykonania wynika z rozmów np. z potencjalnym licencjobiorcą, a od uzyskania których warunkuje on kontynuację rozmów i możliwość zakupu licencji.

Niestety większość uczelni nie gwarantuje swoim jednostkom otoczenia biznesu stałego i stabilnego finansowania. CTT i SC cierpią na brak środków nie tylko na finansowanie prac przedwdrożeniowych i wyjazdy na targi, ale nawet na utrzymanie kadry i na ochronę patentową inną niż w Polsce. A te źródła kapitału, które wydają się być dostępne obecnie na rynku w nadmiarze, tj. różnego rodzaju fundusze kapitałowe, w tym zalążkowe, są zarezerwowane przed wszystkim dla tych przypadków, w których rozważana jest komercjalizacja pośrednia, czyli założenie spin-offa.

Dlatego tak bardzo doceniany jest program Ministerstwa Nauki i Szkolnictwa Wyższego „Inkubator innowacyjności” (dalej: II), którego trzecia edycja dobiega końca. Ze środków II możliwe jest sfinansowanie wielu działań podejmowanych z sukcesem przez CTT i SC, w tym finansowanie (kwotą do 100 tys. na jeden projekt wynalazczy lub innowacyjny) badań przedwdrożeniowych, których celem jest taki rozwój wynalazku lub innowacji, który sprzyja podniesieniu poziomu gotowości technologicznej, a co za tym idzie wiarygodności i minimalizacji ryzyka wdrożenia tych wynalazków i innowacji. Badania przedwdrożeniowe to również sposób na udzielenie odpowiedzi na jak największą liczbę pytań podmiotów gospodarczych zainteresowanych wdrożeniem dofinansowanych projektów wynalazczych i innowacji. W realizacji projektów II siły swe łączą CTT i SC, tworząc konsorcja nie tylko wewnątrzuczelniane, ale również międzyuczelniane. Sprzyja to wzajemnemu inspirowaniu się i uczeniu się, budowaniu zespołów interdyscyplinarnych oraz docieraniu do większej liczby potencjalnych odbiorców uczelnianych 
technologii i innowacji. W ramach programu "Inkubator innowacyjności+”, który zakończył się w pierwszym kwartale 2019 r., projekty zrealizowało 20 konsorcjów, w skład których wchodziło 53 CTT i SC. Wskaźniki osiągnięte w programie potwierdzają jednoznacznie duży potencjał praktyczny uczelnianych rezultatów oraz wysokie kompetencje kadry odpowiadającej za cały proces komercjalizacji. W efekcie realizacji programu przeprowadzono 571 prac B+R (tzW. prac przedwdrożeniowych, o których mowa wyżej), dokonano 1206 zgłoszeń patentowych, podpisano 1633 umowy dotyczące współpracy między środowiskiem naukowym i otoczeniem gospodarczym (w tym umowy licencyjne, sprzedaży, na wykonanie usług badawczych itp.) oraz utworzono 64 spółki spin-off/spin-out. Wszystkie planowane we wnioskach o dofinansowanie wskaźniki zostały znacznie przekroczone, względem pierwotnych oczekiwań ${ }^{6}$. Obecnie 24 konsorcja złożone z 60 uczelnianych podmiotów otoczenia biznesu realizują kolejną edycję programu pod nazwą „Inkubator innowacyjności 2.0” i już teraz można powiedzieć, że podobnie jak w pierwszych dwóch edycjach osiągnięte wyniki przerosną oczekiwania.

Kolejnym ważnym źródłem finansowania uczelnianych działań okołotransferowych miała stać się wydzielona część dotacji statutowej, a obecnie subwencji, którą otrzymują uczelnie. W latach 2017 i 2018, kiedy mowa była jeszcze o dotacji statutowej, ustawowo zagwarantowano, że co najmniej $2 \%$ tej dotacji musi zostać przeznaczone na działania związane z komercjalizacją. Część uczelni zdecydowała się na przekazanie tych środków do dyspozycji centrom transferu technologii, dzięki czemu możliwe było utrzymanie kadry, sfinansowanie kolejnych badań przedwdrożeniowych i dostępu do zewnętrznych ekspertyz, a także organizacji szkoleń i wydarzeń sprzyjających procesowi komercjalizacji. Niestety, obecne przepisy, pomimo że w katalogu kosztów, jakie mogą być finansowane z subwencji, ujmują koszty związane z komercjalizacją, to jednak nie definiują wysokości dofinansowania, jakie należy przeznaczyć na ten cel. Powoduje to, że uczelnie w dalszym ciągu niechętnie wydatkują środki na transfer wiedzy i technologii, stawiając jednocześnie wysokie wymagania i oczekiwania wobec CTT i SC.

\section{Porozumienie Akademickich Centrów Transferu Technologii}

Organizacją, która w istotny sposób zaczęła wpływać na działania i wizerunek polskich uczelnianych centrów transferu technologii, stało się Porozumienie Akademickich Centrów Transferu Technologii (PACTT). Jest to nieformalne, dobrowolne zrzeszenie jednostek odpowiedzialnych za komercjalizację bezpośrednią. Sieć została stworzona w 2015 r. przez 6 uczelni, a do dziś rozrosła się do 68 członków. W skład porozumienia wchodzą jednostki odpowiedzialne za transfer wiedzy i technologii uczelni publicznych i niepublicznych, a także przedstawiciele instytutów Polskiej Akademii Nauk, instytutów badawczych oraz państwowe wyższe szkoły zawodowe. PACTT ułatwia biznesowi dostęp do ponad 65 tys. naukowców w całej Polsce i ponad 14 tys. rozwiązań chronionych patentami ${ }^{7}$.

6 Prezentacja dr. Andrzeja Kurkiewicza, zastępcy Dyrektora Departamentu Innowacji i Rozwoju w MNisW, wygłoszona podczas Konferencji Porozumienia Akademickich Centrów Transferu Technologii i Porozumienia Spółek Celowych w Warszawie w dniach 13-15 listopada 2019 r.

7 Http://pactt.pl/. 
Główne cele PACTT to:

- integracja środowiska zajmującego się transferem wiedzy i technologii w warunkach akademickich,

- wymiana wiedzy, doświadczeń, standardów działania i dobrych praktyk,

- rozwój kompetencji zawodowych pracowników centrów transferu technologii,

- współpraca w zakresie komercjalizacji wyników badań naukowych,

- wspólna reprezentacja członków Porozumienia wobec organów administracji publicznej, związków pracodawców oraz innych podmiotów działających na rzecz innowacji i współpracy nauki z biznesem. Reprezentacja ta dotyczy zwłaszcza takich zadań, jak:

- inicjowanie działań proinnowacyjnych o charakterze ogólnokrajowym,

- inicjowanie i opiniowanie zmian prawnych,

- opiniowanie dokumentów strategicznych i działań podejmowanych przez uprawnione organy w zakresie polityki innowacyjnej państwa ${ }^{8}$.

Cele, o których mowa, są realizowane np. podczas regularnych konferencji organizowanych dwa razy do roku, podczas wspólnych wydarzeń, np. takich jak planowane w 2020 r. PACTT SCIENCE BUSINESS INNOVATION EXPO w Łodzi, w postaci wspólnych stoisk wystawienniczych na targach (np. BUDMA) czy też przez bieżący bezpośredni kontakt między pracownikami różnych CTT. PACTT stało się także częścią europejskiego ekosystemu. Dzięki posiadaniu swojego przedstawiciela w europejskiej sieci National Associations Advisory Committee (NAAC), działającej przy Association of European Science and Technology Transfer Professionals (ASTP), komercyjne oferty polskich uczelni i polskich CTT i SC stały się widoczne także dla partnerów zagranicznych.

\section{Podsumowanie}

Biorąc pod uwagę ogólnoświatowe dążenie do gospodarki opartej na wiedzy oraz dynamikę zmian technologicznych, wydaje się, że współpraca nauki z biznesem stała się normą, a nie chwilową modą, która przeminie. Tym samym funkcjonowanie na uczelniach wyższych podmiotów otoczenia biznesu takich, jak CTT i SC oraz inkubatory przedsiębiorczości czy parki technologiczne, o których w niniejszej publikacji nie wspomniano, a które niewątpliwie są też ważnymi elementami ekosystemu innowacji, staje się już powszechne. Współdziałanie naukowców i przedstawicieli biznesu przynosi realne korzyści nie tylko obu stronom tej współpracy, ale także społeczeństwu. Dowodem na znaczenie tej współpracy może być fakt uwzględnienia efektów komercjalizacji pośredniej i bezpośredniej oraz wpływu uczelni na otoczenie społeczno-gospodarcze w kryteriach ewaluacji jednostek naukowych. Korzystne natomiast byłoby, aby istota tej współpracy była także wyrażona w większej liczbie punktów, jakie uzyskuje uczelnia za patenty międzynarodowe czy przychody z komercjalizacji i usług komercyjnych (pożądane są w tym zakresie zmiany rozporządzenia Ministra Nauki i Szkolnictwa Wyższego z 22 lutego

8 Ibidem. 
2019 r. w sprawie ewaluacji jakości działalności naukowej. Tak długo jak znaczenie i waga tych punktów w całej puli do zebrania nie będą istotne, poziom zaangażowania zespołów naukowych w komercjalizację wyników badań będzie niski, a stosunek władz uczelni do działalności z tym związanej nie będzie nadawał wysokiego znaczenia całemu procesowi. Liczne obowiązki dydaktyczne i badawcze, przy jednoczesnym niedocenianiu angażowania się naukowców w proces wdrażania wynalazków (osiągnięcia związane z komercjalizacją nie są doceniane jako ich osiągnięcia zawodowe) powodują, że pracownicy naukowi stawiają tę aktywność na ostatnim miejscu.

Większej liczbie komercjalizowanych rezultatów badawczych będzie także sprzyjać zapewnienie stałego strumienia finansowania działalności CTT i SC, w szczególności łatwo dostępnych środków na podniesienie poziomu gotowości technologicznej uczelnianych pomysłów jeszcze w obrębie aktywności podejmowanych w uniwersytetach przez pomysłodawców. Dotychczasowe doświadczania CTT CITTRU, ale nie tylko, pokazują, że nawet fundusze zalążkowe, takie jak oferowane np. przez fundusze objęte programem „Bridge Alfa”, oczekują zdecydowanie bardziej zaawansowanego stopnia rozwoju uniwersyteckich wynalazków. Kapitał potrzebny np. na wykonanie dodatkowych testów wymaganych przez przedsiębiorstwo a uprawdopodabniających skuteczność oferowanego rozwiązania lub zbudowanie prototypu jest stosunkowo niewielki i powinien być dostępny bez nadmiaru formalności dla zespołów naukowych dążących do wdrożenia własnych wyników badań. Dobrym rozwiązaniem byłoby co najmniej utrzymanie finansowania zbliżonego do badań przedwdrożeniowych w ramach inkubatorów innowacyjności lub stworzenie specjalnego ogólnouczelnianego funduszu, z którego możliwe byłoby sfinansowanie działań koniecznych jeszcze przed rozmowami z właściwymi inwestorami branżowymi i kapitałowymi (niektóre uczelnie już decydują się na dofinansowanie prac przedwdrożeniowych ze środków własnych, np. Uniwersytet Jagielloński). Propozycje finansowego wsparcia procesu komercjalizacji w Europie wypracowało też ASTP i NAAC. 23 stycznia 2020 r. reprezentanci tych organizacji przedstawili Komisji Europejskiej propozycję opisaną w dokumencie Embedding Knowledge Transfer Offices (KTOs) in Horizon Europe Projects. W myśl tej propozycji w każdym projekcie finansowanym ze środków europejskich powinien być wyodrębniony $5 \%$ budżet na cele związane z komercjalizacją wyników projektu, będący w dyspozycji CTT.

Z kolei istotną bolączką startupów przyuczelnianych jest brak wystarczającej liczby kadry menedżerskiej, która z jednej strony miałaby doświadczenie w prowadzeniu nowych biznesów technologicznych, z drugiej zaś będzie chciała zaangażować się w działalność za wynagrodzenie oferowane przez początkującą spółkę. W zarządzaniu spółką celową, która obejmuje udziały w tych startupach, nie pomaga też włączenie SC w zakres oddziaływania ustawy o zasadach zarządzania mieniem państwowym ${ }^{9}$. Wymagania wynikające z tej ustawy, w tym stawiane członkom zarządów i rad nadzorczych spółek celowych, są nieadekwatne do zakresu działania tych specyficznych form działalności biznesowej uczelni. Do zasiadania w organach SC powinni zostać dopuszczeni nie tylko ekonomiści, prawnicy czy doktorzy nauk technicznych, ale też

9 Ustawa z 16 grudnia 2016 r. o zasadach zarządzania mieniem państwowym, Dz.U. poz. 2259. 
doktorzy innych nauk specyficznych dla obszaru działalność SC (np. nauk medycznych, jeśli akurat spółka celowa powoływana jest przez uczelnię medyczną).

Pozytywne jest natomiast to, że co do zasady przepisy prawa mające związek z komercjalizacją wyników badań w uczelniach wyższych nie wymagają istotnych zmian, a co najwyżej niewielkich korekt, doprecyzowania lub ujednolicenia ich interpretacji.

\section{Bibliografia}

Konopka-Cupiał G., Komercjalizacja wyników badań naukowych spod znaku UJ, „Alma Mater” 2017, nr 196.

Kurkiewicz A., prezentacja wygłoszona podczas Konferencji Porozumienia Akademickich Centrów Transferu Technologii i Porozumienia Spółek Celowych w Warszawie w dniach 13-15 listopada 2019 r. ASPP NAAC, Embedding Knowledge Transfer Offices (KTOs) in Horizon Europe Projects, https://www.astp4kt.eu/ resource-center/publications/.

\section{Akty prawne}

Ustawa z 30 czerwca 2000 r. - Prawo własności przemysłowej, Dz.U. 2001, nr 49, poz. 508, ze zm. Ustawa z 16 grudnia 2016 r. o zasadach zarządzania mieniem państwowym, Dz.U. poz. 2259. Ustawa z 20 lipca 2018 r. - Prawo o szkolnictwie wyższym i nauce, Dz.U. poz. 1668.

\section{Strony internetowe}

Http://instytutpb.com.

Http://pactt.pl.

Https://scuep.pl. 